Малджиева, В. (2018). Принципи на формалното описание на българските изменяеми лексеми като компонент на нормативната граматика. Slavia Meridionalis, 18. https://doi.org/ 10.11649/sm.1696

Maldzhieva, V. (2018). Principi na formalnoto opisanie na bŭlgarskite izmeniaemi leksemi kato komponent na normativnata gramatika. Slavia Meridionalis, 18. https://doi.org/10.11649/sm.1696

\title{
Вяра Малджиева
}

Университет „Николай Коперник“ в Торун

\section{Принципи на формалното описание на българските изменяеми лексеми като компонент на нормативната граматика}

\author{
Grammatica ars obligatoria \\ 'Граматиката е изкуство да се владее задължителното'
}

Предназначението на описателния компонент на нормативната граматика е да осигури „детайлно описание на инвентара от граматични средства на българския език, както и на тяхното функциониране” („Проект“, 2017), „подробно и внимателно описание на книжовноезиковата граматична система" (Станчева, Томов, Паскалев, Кунева, \& Микова, 2017). Това означава (особено по отношение на формалната част) езиковите факти да бъдат описани по възможно най-точен и изчерпателен начин, без да бъдат априорно интерпретирани - това е условието те да послужат като обективен материал за нормативна интерпретация, да позволят точното обособяване и диагностициране на следващия етап на нормативните проблеми.

This work was supported by the Polish Ministry of Science and Higher Education. Competing interests: the author is a member of the Editorial Team of this journal. Publisher: Institute of Slavic Studies, Polish Academy of Sciences.

This is an Open Access article distributed under the terms of the Creative Commons Attribution 3.0 PL License (creativecommons.org/licenses/by/3.0/pl/), which permits redistribution, commercial and non-commercial, provided that the article is properly cited. (c) The Author(s) 2018. 
Постигането на тази цел изглежда възможно, ако към описанието се подходи като към задача за създаване на универсална класификация на формите на българския език, разбирана в духа на А.А. Зализняк, като класификация, позволяваща „да се проникне по-дълбоко в природата на разглежданата съвкупност от обекти” (Зализняк, 1967, с. 7-8). Става дума за класификация, при която „всеки различителен белег, използван в класификацията, приема някое от своите значения във всеки класифициран обект" (Зализняк, 1967, с. 7)'․ Тя позволява цялото множество от изследвани обекти да да бъде разделено на класове според всеки признак или група от признаци. По тази си особеност универсалната класификация се различава от дървовидната (най-често дихотомична) класификация, която не дава такава възможност, тъй като в нея има поне един различителен белег, по който се характеризират не всички обекти, а само част от тях. Последната се осъществява чрез многостепенно деление (най-често бинарно) на обектите на класове според даден признак (Зализняк, 1967, с. 7) 2 . Всяка дървовидна класификация може да бъде преобраувана в универсална без необходимост от промяна в подялбата на класове, единствено чрез обогатяване с операции, позволяващи да се отрази по-адекватно природата на анализирания обект (Зализняк, 1967, с. 7).

По-долу ще представим построяването на универсална класификация на лексикалните единици на българския език, релевантна за тяхното формално морфологично описание, като преход от дървовидна към универсална класификация.

\section{1. Общи теоретични положения}

1.1. Граматичната и семантичната характеристика на езиковите единици могат и трябва да бъдат описвани независимо. Приемането на такъв постулат не отрича общата теза за наличието на зависимост между тези

1 Във философията и логиката за универсална се смята онази класификационна система, която обхваща целия универсум от знания в дадената област.

2 Типичен пример за дървовидна класификация е делението на части на речта, съдържащо се в съществуващите повече или по-малко възхождащи към латинската традиция (към школската граматика) описания на езиците. Повече за това по отношение на делението на части на речта в българския език - виж по-долу 2.0.1.). 
две характеристики, а е резултат от отчитането на нейната сложност - на липсата на едно- еднозначно съответствие между тях в естествения език). Едва на следващия етап на формите могат да се приписват значения (т.е. да се определят функциите на формите да изразяват (най-често повече от едно) значения. Смятам, че пренебрегването на този постулат води до смесване на закономерностите, действуващи в плана на израза, с тези от плана на съдържанието и нарушава точността на анализа. Очевидно е, че описанието на граматичните свойства на дадена езикова единица е невъзможно без интуитивното разбиране на нейното значение. Очевидно е обаче също така, че да се укаже семантичният източник напр. на различието в поведението на думите, още не означава да се обясни различната им граматична характеристика (в това число и различното им функциониране).

Постулатът за независимо описание на формата и съдържанието на езиковите единици е особено важен за описанието, което в следващия етап подлежи на нормативна интерпретация, ако трябва да бъдат изпълнени нейните задачи.

Възлово за описанието, подчинено на този принцип, се явява разбирането на многозначността - струва си да се отбележи, че в традиционното разбиране дефинициите на омонимията и полисемията са по същество диахронни, в синхронен смисъл те и двете представляват едно и също явление, а именно липса на еднозначно съответстветствие между форма и значение. Приемам (в духа на полската школа), че от синхронна гледна точка може да се употребява общ темин - омонимия (='едноименност') (срв. по-долу 2.1.1. и 3.2.4.).

1.2. Граматичната характеристика трябва да предхожда семантичната, особено що се отнася до лексикалните единици. Описанието на граматичните свойства на дадена лексикална единица, макар и невъзможно без интуитивното разбиране на значението ѝ, не изисква нейното предварително семантично интерпретиране, докато граматичната ѝ интерпретация може да повлияе и на експликацията на значението ${ }^{3}$.

1.3. Под лексикална единица в духа на оперативната граматика на А. Богуславски (срв. Bogusławski, 1978) се разбира всяка прекъсната

3 Тук изцяло приемам схващанията по този въпрос на М. Гроховски (срв. Grochowski, 1986, с. 26). 
или непрекъсната редица от диакритични знаци (за писмената реч - peдица от букви) с глобално значение, т.е. редица, която не може да бъде семантично поделена на по-малки значещи редици, които да са елементи на отворени субститутивни класове. Отвореният субститутивен клас е клас, чиито елементи могат да се поддават на взаимна субституция и който може да бъде общо характеризиран (назован) от семантична гледна точка. Затворен субститутивен клас това е клас, който не може да бъде описан по друг начин освен чрез изброяване на влизащите в него елементи. Така според тази дефиниция за лексикални единици могат да се смятат изрази като пиша, хубав, нормално, зелен хайвер, важна клечка и др., но не и изрази като хубав човек, пиша нормално, зелено дърво и др., тъй като те са съставени от две лексикални единици, представители на отворени субститутивни класове (за принципите за определяне на лексикалните единици вж. още Grochowski, 1982, 1986). В зависимост от характера на редицата от знаци лексикалните единици могат да бъдат полисегментни (представляващи прекъсната редица от диакритични знаци) и моносегментни (представляващи непрекъсната редица от диакритични знаци). Лексемите, които са основен прицел на описанието на този етап, най-често ${ }^{4}$ са моносегментни лексикални единици.

1.4. Граматичната характеристика на изменяемите лексикални единици включва тяхната морфологична и синтактична характеристика. При неизменяемите лексикални единици тя се свежда до тяхната синтактична - функционална и дистрибутивна характеристика. Под функционална характеристика тук ще се разбира описание на синтактичните връзки, в които даден израз влиза с други изрази. Дистрибутивната характеристика се разбира като описание на множеството граматически правилни контексти, разглеждани като състоящи се от категориално (граматично) характеризирани изрази - словоформи, в които може да се появи даден израз. Този текст се ограничава до въпросите на формалното описание в граматиката на изменяемите лексеми (моносегментни лексикални едници).

4 Тук са необходими известни уговорки, свързани с разликите между словоформа и текстова (графична) дума - виж по-долу 2.1.4. 


\section{2. Дихотомична формална класификация} на лексемите в българския език

2.0. Основна част от граматичната характеристика на лексикалните единици представлява установяването на принадлежността им към дадена част на речта.

2.0.1. Да се установи принадлежността на една лексикална единица към дадена част на речта, при положение че се приемат постулатите, изложени по-горе, означава да се изхожда от класификация на частите на речта, в която те са така дефинирани, че самото причисляване на лексикалната единица към някоя от тях автоматично дава основната за нейната граматична характеристика информация. Традиционната класификация на частите на речта, която 1) се основава на хетерогенни критерии и 2) в много отношения не изпълнява изискванията на правилното логическо деление (напр. не оперира с точно определени, единни на всяко делитбено стъпало критерии), не може да служи за решаването на тази задача 5 .

2.0.2. Необходима е класификация на лексикалните единици, а в частност на лексемите, основаваща се на граматични (морфологични и синтактични) критерии, приложени според принципите на правилното логическо деление. В случая това означава, че делението се провежда стъпаловидно, по дихотомичен принцип (т.е. изключително въз основа на наличието или липсата на даден признак), в резултат на което класовете са противопоставени по двойки, а сумата на всичките класове дава цялото изследвано множество. Същевременно в езиците с богата флексия, каквито са славянските, е по-добре при анализа и класификацията на лексемите да се прилагат най-напред съответните морфологични (флективни) критерии, а след това синтактичните. Противоречието между тези два критерия е само привидно, доколкото изменящите се по определен начин думи обикновено изпълняват определени синтактични функции (срв. 2.2.3. и 3.1.3.) (макар че могат да

5 Срв. напр. местоимението, което се поставя в опозиция на други части на речта само по семантичен критерий, същото важи за числителното име; повечето неизменяеми части пък влизат в опозиция с други части на речта само по синтактичен критерий. Съществува огромна литература, посветена на критиката на традиционната красификация на частите на речта, която тук няма да се разглежда. 
се срещат и в нетипични и малко характерни функции). Освен това прилагането на морфологичните критерии преди синтактичните е мотивирано и от факта, че „при описанието на езика флексията играе решаваща роля във фазата, която естествено предхожда класификацията на лексемите - в определянето (абстрахирането) на отделните лексеми" (Saloni, 1974a, c. 7).

2.0.3. Граматична класификация на лексемите (приблизително: частите на речта) е необходима не само за да се очертаят точно границите на класовете лексикални единици, но и за да може да се проведе както разграничаването вътре в подмножествата, така и конкретната граматична характеристика на всяка от тях - т.е. да се премине към универсална класификация (виж по-долу 3.).

2.1. Определянето на класифицираните обекти и класификационните признаци (критерии) изисква приемане на вътрешно непротиворечива система от релевантни понятия и съответно дефиниции на термините 6 И така:

2.1.1. Под лексема се разбира множество от словоформи с идентична или регулярно диференцирана семантична характеристика, които се намират в регулярна опозиция една спрямо друга според стойностите на присъщите им граматични категории (виж по-долу 2.1.4.-5.) ${ }^{7}$.

Ако лексемата се разбира като набор от словоформи, конституиран от общи граматични, семантични и прагматични характеристики, следва да се приеме, че при различия дори в един от елементите, може да се говори за друг набор и следователно за омонимия (в това число и граматична) ${ }^{8}$. Условието е твърде строго, затова решението за границите на омонимията трябва да се вземе с оглед към релевантността на дадена характеристика за нормативното описание. Това особено се отнася за

6 Това се налага още повече от факта, че става дума за термини, които битуват в граматическото описание с различно съдържание в зависимост от основните постулати на анализа.

7 Срв. също Мелчук, 2013, с. 134: „Лексемата е множество от словоформи и/или словосъчетания, които се отличават помежду си само по словоизменителните си значения".

8 С поклон към традицията и към бръснача на Окам в някои случаи на второстепенни граматически (предимно синтактични) различия може да се говори за полифункционалност (напр. при наречията). 
основанията прагматичната характеристика да бъде основа за отделяне на омонимни лексеми (срв. по-долу 3.2.1.).

2.1.2. Проблем при въвеждането на единна и непротиворечива система от термини представлява терминът дума, използван традиционно с повече от едно значение в рамките дори на едно и също описание. В предлаганата тук терминологична мрежа дума ще се разбира преди всичко като графична дума (сегмент) и ще се използува за означаване на „редица букви между две съседни шпации” (Блумфийлд, 1968). Същественото е, че така разбираната дума 1) не е интерпретирана граматично и/или семантично редица 2) не е непременно субстанциален израз на словоформа (словоформата може да се състои от повече графични думи - срв. по-долу 2.1.4.)

2.1.3. С термина израз ще бъдат означавани всички неинтерпретирани (граматично и/или семантично) думи и групи думи, т.е. всички произволни (с прекъсване или без) редици от диакритични елементи на дадения език'.

2.1.4. Словоформата (формата) тук се разбира като дума или съчетание от думи, отговарящо на определени условия, интерпретирана граматично (т. е. с приписан набор от граматични значения - повече за това - 3.1. $)^{10}$.

2.1.4.1. По своите свойства словоформите се противопоставят от една страна на морфите или редиците от морфи, а от друга страна - на словосъчетанията (групите словоформи) (срв. Мелчук, 2013, c. 236). Различителни свойства на словоформата са отделимостта ${ }^{11}$,

9 Дори интуитивно е ясно, че единици от типа напр. на бълг. ако... то..., ни... ни..., на щрек от една страна и гледа като теле в железнииа, през куп за грош, дебела работа - от друга, не могат да бъдат причислени към някоя от частите на речта на едни и същи основания. Опитът да бъде установена принадлежността към дадена част на речта на лексикалните единици, състоящи се от повече от една дума, без при това да се влиза в противоречие със системата от класификационни признаци, изисква определянето на допълнителни условия.

10 Срв. също Зализняк, 1967, с. 20: 3:20: „двустранна текстова единица, притежаваща израз и съдържание".

11 Мелчук, 2013, с. 237: „Като правило словоформата може да бъде отделена от останалата част на даден автономен знак - при запазване на всички семантични отно- 
дистрибутивната вариативност ${ }^{12}$, преместимостта ${ }^{13}$ и анафоричната непроницаемост ${ }^{14}$.

2.1.4.2. Инвентарът от словоформи, участващи в строежа на българския израчански израз, се определя от: 1) граматичните категории, присъщи на българския език, и техните стойности (граматични значения) и 2) класовете лексеми в българския език.

\subsection{5. Граматичната (морфологичната) категория представлява} регулярна опозиция, чиито признаци се изразяват морфологично (членовете ѝ могат да бъдат различени въз основа на морфологични изразители), в някое от множествата лексеми на даден език (в някой граматичен клас - виж по-долу) или в множеството от словоформи на една лексема.

От дефиницията следва, че по същността си граматичната категория е привативна, т.е. противопоставя наличието на един признак на наличието на друг, не е противопоставяне на наличие и липса на един признак. Иначе казано, за редовната опозиция са необходими най-малко два елемента. Това дефиниционно изискване е съществено за определянето на инвентара от граматични категории на дадения език ${ }^{15}$. Така напр. числото е граматична категория на българския език

шения - чрез други безусловни словоформи, а частта от словоформа - не може (с някои изключения...)”.

12 Мелчук, 2013, с. 237: „Като правило частта от словоформа се съчетава с много по-ограничен клас от знаци, отколкото словоформата; достатъчно разнообразната дистрибуция на даден знак е белег за това, че той е словоформа”.

13 Мелчук, 2013, с. 237: „Като правило за частта от словоформа промяната на нейната позиция е недопустима (с някои изключения ...); сравнителната свобода за преместване на знака (по отношение на някакъв друг знак и при запазване на семантичните отношения между тях) е белег за това, че той е словоформа. Случаите, когато част от словоформа може да се премества без при това да се нарушават съществуващите семантични отношения, са крайно редки...”.

14 Мелчук, 2013, с. 238: „Анафорична непроницаемост на словоформата (Postal, 1969). Като правило частта от словоформата не може да бъде антецедент на анафорично местоимение; от това гледище словоформата сякаш образува „анафоричен остров“.” Като пример могат да послужат словоформите на сложните думи - така във вестникопродавец първият компонент - елементът на сложната дума - вестник - е недостъпен за местоименна анафора, т.е. не може да служи за антецедент.

15 Срв. Мелчук, 2013, с. 295: „Всяка категория обединява всички значения, които взаимно се изключват в една и съща позиция по чисто семантични причини (...) От това, че всички елементи на една категория се изключват един друг, следва, че при 
(защото всяка словоформа на съществително име е или за единствено или за множествено число), за разлика напр. от умалителността (защото не може да се каже, че всяка форма и дори всяко съществително име е или умалително или неумалително) ${ }^{16}$.

2.1.6. Граматичните категории имат различни езикови (системни) и текстови функции ${ }^{17}$. Според тях се различават флективни (словоизменителни) и селективни (синтактични) граматични категории.

нормални условия никое езиково значение не може да се характеризира едновременно чрез други две значения, принадлежащи към една и съща категория. Например никакъв 'X' не може да бъде едновременно 'червен' и 'син', т.е. 'червен син X'; никое съществително не може да бъде едновременно и в единствено и в множествено число и т.н. (...) Категорията никога не съдържа по-малко от два елемента - доколкото значенията на една категория по определение се изключват едно друго, а за това се изискват поне две противопоставени значения".

16 Това условие е съществено за решаването на въпроса за мъжколичиния род - виж 4.2.

17 Въпреки че този проблем е извън обсега на вниманието на етапа на формалното описание, си заслужава да се отбележи, че морфологичните категории, характеризиращи словоформите в изреченския израз (които традиционното граматическо описание третира по еднотипен начин и без оглед към класовете лексеми) в различна степен функционират като изразители на съставящи от семантичната структура на изречението. Поради това те трябва да бъдат разглеждани във връзка с класовете лексеми, които характеризират. Една част от тях - родът на съществителното име и видът на глагола, определяни като класификационни, не участват в репартицията на смислите, нито в сигнализирането на синтактичните връзки между словоформите в изречението. Въз основа на тях лексемите от даден клас се делят единствено на подкласове, задаващи начина на образуване на словоформите им и/или техния брой. Друга част от морфологичните категории за отделните класове лексеми не са изразители на съдържателни елементи от изречението. Те само сигнализират акомодацията на подчинения член на глаголната или именната фраза с главния. В този смисъл те имат само (формално-)синтактична функция. Такива са родът и числото на прилагателното и числителното име и лицето, числото и родът на глагола. Останалите морфологични категории имат семантични функции. Морфемите, маркирани с техни стойности, са морфологични изразители на съставящи от семантичната структура на изречението (като се изключат редките случаи, когато техните стойности се изискват от синтактично главен член - срв. напр. т. нар. съгласуване на времената). Така лицето на съществителните - лични местоимения, изразява участника в комуникативния акт, числото на съществителното име е изразител на количеството като елементи от дикталното съдържание. Времето и наклонението на глагола могат да бъдат изразители на актуализиращите категории темпоралност и модалност, а членът на прилагателното, числителното или съществителното име е изразител на определеността. 
2.1.6.1. Флективна (словоизменителна) е граматичната категория, основана на опозицията в множеството словоформи, принадлежащи на една лексема, т.е. това е категория, според която се изменя даден клас лексеми (срв. Saloni \& Świdziński, 1985) ${ }^{18}$. В текста флективната категория най-често е съгласувателна (изразява съгласуването на подчинения елемент от синтактичната конструкция с главния, напр. на прилагателното име със съществителното име по род или на глагола със съществителното име по число).

2.1.6.2. Селективна (синтактична) е граматичната категория, чиито стойности всички лексеми от даден клас изискват от подчинения елемент в синтактичната конструкция (напр. всяко съществително име изисква определена стойност на категорията род от прилагателното име; всяко числително (главно) име изисква определена стойност на категорията число от съществителното име) или от техни словоформи (напр. словоформите на съществителното име с определна стойност изискват от прилагателното име словоформи със същата стойност (срв. Saloni \& Świdziński, 1985, c. 99-106) ${ }^{19}$.

2.1.6.3. При построяването на дихотомична граматична класификация, а впоследствие и на универсална класификация, релеватна за формалното морфологично описание, от основно значение са флективните категории.

2.1.7. Флективната категория има следните свойства (срв. Мелчук, 2013, с. 296 сл.):

- тя е задължителна по отношение на даден клас - ако говорещият използва лексема от дадения клас, той е длъжен да избере определна от езиковите правила нейна стойност;

18 Това означава, че не може да се говори за граматична категория изобщо, а за граматична категория по отношение на даден клас лексеми. Така напр. родът е селективна (и класификационна) категория за съществителното име и словоизменителна категория за прилагателното име.

19 От гледна точка на езиковата структура част от граматичните категории се определят като класификационни - това са категориите, основани на опозиция в множеството на лексемите на даден език (те делят това множество на класове в рамките на системата); всяка лексема от даден клас има приписана определена постоянна стойност на тази категория (напр. род за съществителните имена и аспект за глаголите). Селективните категории в някои случаи могат да бъдат решаващи за причисляването на отделни лексеми към даден граматичен клас (виж по-долу 2.2.3.). 
- тя е редовна (регулярна) ${ }^{\mathbf{2 0}}$.

Като неуниверсално свойство на флективната категория се посочва и това, че тя е повсеместна (вездесъща), т.е. нейните изразители (изразителите на нейните стойности) обикновено се срещат често в речта.

2.2. В тази работа се приемат принципите на граматичната класификация на лексемите, направена за полския език от 3. Салони (Saloni, 1974a, 1974b, срв. също Saloni \& Świdziński, 1985)²1. Тази класификация е валидна за всички синтетични славянски езици ${ }^{22}$. Тя обаче трябва да бъде адаптирана към българския език, предвид на ограничената

20 Срв. Мелчук, 2013, с. 296:

„Нека ни е дадена категорията С, съдържаща значенията ' $\mathrm{s}_{\mathrm{i}}$ ':

$\mathbf{C}=\left\{\mathrm{s}_{1},{ }^{\prime}, \mathrm{s}_{2}, \ldots, \mathrm{s}_{\mathrm{n}}\right.$ ' $\left.\mid \mathrm{n}>2\right\}$.

$\mathbf{C}$ се нарича словоизменителна категория за класа от знаци $\mathbf{K}=\left\{\mathbf{K}_{\mathbf{j}}\right\}$ в езика $\mathbf{L}$, ако се изпълняват следните две условия:

1. (а) При всеки знак $\mathbf{K}_{\mathbf{j}}$ задължително се изразява някое, и при това само едно, от значенията ' $\mathrm{s}_{\mathrm{i}}$ '

и

(b) всяко значение ' $s_{\mathbf{i}}$ ' задължително се изразява поне при един знак $\mathbf{K}_{\mathbf{j}}$.

2. Значенията ' $\mathrm{s}_{\mathrm{i}}$ ' се изразяват редовно, т.е.:

(a) всяко ' $s_{i}$ ' е строго композиционно (резултатът от обединяването на всяко ' $s_{i}$ ' с един или друг $\mathbf{K}_{\mathbf{j}}$ винаги може да бъде изчислен по достатъчно общо правило);

(b) ако класът К е многоброен, тогава за всяко ' $\mathrm{s}_{\mathrm{i}}$ ' броят на елементарните знаци, изразяващи ' $s_{i}$ ', е достатъчно малък и дистрибуцията (= разпределението) на тези знаци се описва по достатъчно общи правила;

(c) повечето от значенията ' $\mathrm{s}_{\mathrm{i}}$ ' се изразяват при всички или почти всички знаци от класа К.” (срв. също Laskowski, 1998).

21 За основа на класификацията са послужили някои от правените преди това опити от подобен тип. Срв. напр. класификациите, основани на синтактичен критерий - за английски език на Ч. Хокет (Hockett, 1968), в категориалната граматика на К. Айдукевич (Ajdukiewicz, 1985, с. 222-242). Класификацията, която се приема тук, е най-близка до тази на Ф. Фортунатов за руски език (Фортунатов, 1956, с. 157-160) и на В. Пожежински за полски език (Porzeziński, 1923, с. 129-150). Срв. също излезлите по-късно РГ, 1982 и Laskowski, 1998. Макар и в неявен вид такава класификация се приема и в Пенчев, 1984.

22 В резултат от многостепенно дихотомично деление по морфологични (флективнн) признаци [+/- изменяемост] [+/- изменяемост по падеж] [+/- изменяемост по род], [+/- изменяемост по число] , [+/- изменяемост по лице] се абстрахират изменяемите части на речта: (1) съществителни имена, (2) прилагателни имена, (3) числителни имена, (4) лични глаголи, (5) безлични глаголи; а по синтактичните признаци [+/- самостоятелна употреба], [+/- свързваща функция], [+/- падежно управление] - неизменяемите части на речта: (6) наречия - частици, (7) предлози, 
флективност на имената (съществителни, прилагателни и числителни). Изглежда че възможните пътища са два - или да се запази признакът [+/- изменяемост по падеж], като се приеме, че субституцията с лично местоимение ще дава възможност да се различават поне пряк и косвен падеж, или вместо този признак за българския език да се въведе признак [+/- членуваност] (подобно предложение се съдържа в Леков, 1972, c. 112). Първият път трябва да бъде отхвърлен като неудовлетворителен както теоретически, така и практически доколкото: 1) класификацията не предвижда местоименията като отделен клас; 2) статусът на словоформите мене, тебе, него... като падежни форми е дискусионен; 3) субституцията с лично местоимение няма да даде резултати по отношение на прилагателните и числителните имена. В същото време въвеждането на признака [+/- членуваност] има достатъчна различителна сила - успешно противопоставя имената на глаголите, а освен това не нарушава единството на признаците на този етап на деление, защото е също морфологичен (флективен).

2.2.0. Дървовидната формално-граматична класификация на българските лексеми може да се направи по пътя на многостепенно дихотомично деление чрез прилагане на следните морфологични (флективни) и синтактични критерии:

1. [+/- изменя се], 2.1. [+/- изменя се по член], 3.1. [+/- изменя се по число], 4.1. [+/- изменя се по род], 3.2. [+/- изменя се по лице], 2.2. [+/- употребява се самостоятелно], 3.3. [+/- има свързваща функция], 4.2. [+/- може да свързва съществително име и глагол], 5. [+/- може да свързва лексеми с една и съща синтактична функция], 6. [+/- може да се отнася до целия изреченски израз].

(8) съюзи и (9) междуметия. Към най-общо представената класификация трябва да се направят следните допълнения:

Естествен резултат от изоставянето на семантичния критерий е липсата на клас, съответствуващ на традиционните местоимения - те се разпределят между класове (1), (2), (3) и (6). Лексемите, традиционно определяни като числителни имена, в полски език се разпределят между класове (1), (2), (3) и (6). Както и самият автор подчертава, клас (6), абстрахиран чрез прилагане само на „отрицателните” членове на всички опозиции, използувани в класификацията, е твърде нееднороден и може да бъде делен по-нататък по синтактични признаци (Saloni, 1974b, c. 100). 


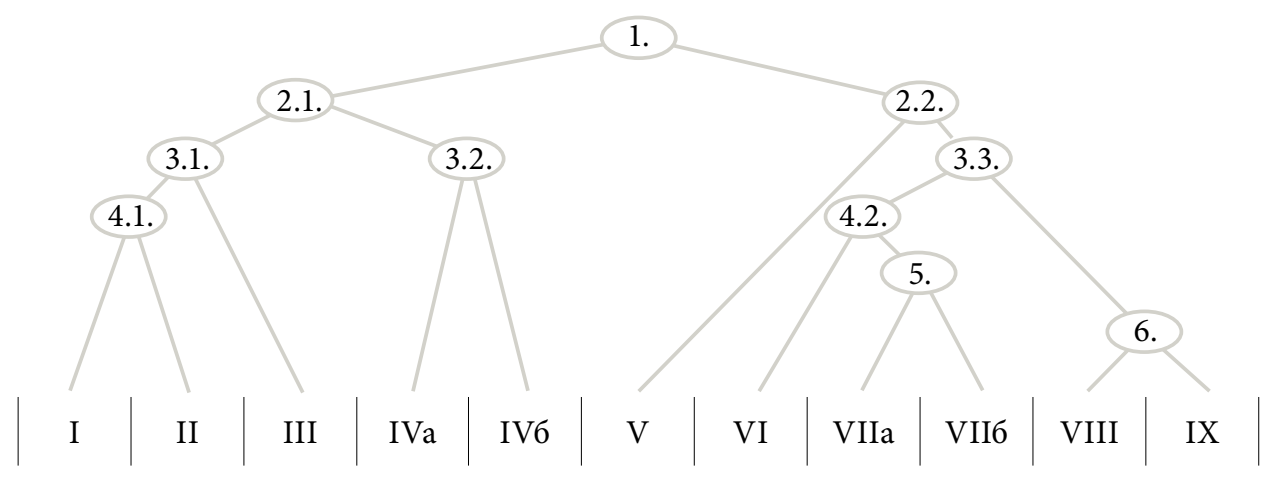

2.2.1. В резултат на делението се получават следните непресичащи се класове лексеми със своята характеристика, която може да бъде изведена като сума от делитбените белези и техните стойности: I. прилагателни имена; II. съществителни имена; III. числителни имена ${ }^{23}$; IV. глаголи (IVa. лични; IVб безлични); V. междуметия; VI. предлози; VII. съюзи (VIIа съчинителни; VIIб подчинителни); VIII. частици; IX. наречия ${ }^{24}$.

2.2.2. Съществена за морфологичната характеристика на българските лексеми на този етап от описанието е лявата част на класификацията, в която са абстрахирани изменяемите класове лексеми.

2.2.3. Причисляването на дадена лексема към определен граматичен клас изисква да се вземат пред вид не само флективните, но и селективните категории, които могат да ѝ бъдат приписани. Това особено се налага в случаите, когато след „изчерпване” на морфологичните критерии остават групи изрази, чиято квалификация може да бъде направена само с помощта на синтактични критерии.

23 Противопоставянето на съществителните и числителните имена по признака [изменяемост по род] в значителна степен зависи от решаването на въпроса колко граматични значения на категорията „род” трябва да се приемат за отделните славянски езици, напр. дали „мъжколичността” ще се приеме за стойност на граматичната категория „род” за българския език (срв. мъжколичните форми в полски език и т. нар. мъжколични числителни бройни в български език - повече за това виж по-долу 4.2.).

${ }^{24}$ Най-добре би било всяка от класификациите да си служи с отделни термини, с цел 1) да се избегне многозначността на термините (тя сама по себе си е порок за един термин), особено що се отнася до традиционните термини; 2) да е ясно от самия термин кой от аспектите на езиковата единица представя. Струва ми се най-разумно и в някакъв смисъл естествено традиционните названия на (по-голямата част от) частите на речта да бъдат „резервирани” за (формално-)граматичната (морфологична и синтактична) класификация. 
Категории на класовете изменяеми лексеми

\begin{tabular}{|l|l|l|}
\hline \multirow{2}{*}{ Граматичен клас лексеми } & \multicolumn{2}{|c|}{ Граматични категории: } \\
\cline { 2 - 3 } Прилагателно име & \multicolumn{1}{|c|}{ флективни } & \multicolumn{1}{c|}{ селективни } \\
\hline Числително име & $\begin{array}{l}\text { род } \\
\text { число } \\
\text { членуваност }\end{array}$ & $\begin{array}{l}\text { род } \\
\text { членуваност }\end{array}$ \\
\hline Съществително име & $\begin{array}{l}\text { число } \\
\text { членуваност }\end{array}$ & $\begin{array}{l}\text { род } \\
\text { члслонуваност } \\
\text { лице }\end{array}$ \\
\hline Глагол & $\begin{array}{l}\text { лице } \\
\text { род } \\
\text { число }\end{array}$ & \\
\hline
\end{tabular}

Селективните категории на имената са изведени от функционалните и диструбитувни характеристики на техните словоформи в текста, отразени в таблицата.

Синтаксис на имената

\begin{tabular}{|c|c|c|c|c|}
\hline & главен член & В конструкция с: & подчинен & н в конструкция с: \\
\hline \multirow{6}{*}{ 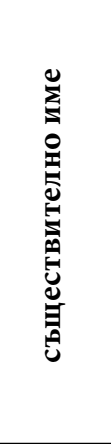 } & прилагателно & хубава $\rightarrow$ жена & числително & $\begin{array}{l}\text { три } \rightarrow \text { жени } \\
\text { три } \rightarrow \text { молива }\end{array}$ \\
\hline & $\begin{array}{l}\text { сьществи- } \\
\text { телно }\end{array}$ & жена $\rightarrow$ хирург & предлог & $\begin{array}{l}(\text { готовност) за } \\
\text { помом } \\
(\text { пиша) на } \rightarrow б а б а\end{array}$ \\
\hline & предлог & $\begin{array}{l}\text { готовност } \rightarrow \\
\text { за }(\text { помоч) }\end{array}$ & глагол & чета $\rightarrow$ писмо \\
\hline & наречие & къщзата $\rightarrow$ насреща & $\begin{array}{l}\text { съществи- } \\
\text { телно }\end{array}$ & жена $\rightarrow$ хирург \\
\hline & глагол & жена $\rightarrow$ върви & & \\
\hline & изречение & решение $\rightarrow$ да дойда & & \\
\hline \multirow{3}{*}{ 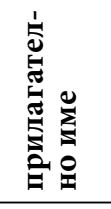 } & наречие & 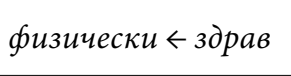 & $\begin{array}{l}\text { съществи- } \\
\text { телно }\end{array}$ & хубава $\leftarrow$ жена \\
\hline & предлог & готов $\rightarrow$ за помош & глагол & $\begin{array}{l}c z \mathcal{M} \leftarrow x y б a в \\
\text { чвстввам } c e \leftarrow 3 д p a в\end{array}$ \\
\hline & изречение & готов $\rightarrow$ да дойде & предлог & (правя се) на умен \\
\hline \multirow{2}{*}{ 卢曷导导 } & $\begin{array}{l}\text { съществи- } \\
\text { телно }\end{array}$ & $\begin{array}{l}\text { три } \rightarrow \text { жени } \\
\text { три } \rightarrow \text { молива }\end{array}$ & $\begin{array}{l}\text { съществи- } \\
\text { телно }\end{array}$ & трима $\leftarrow$ мбже \\
\hline & прилагателно & иели $\leftarrow$ три (часа) & & \\
\hline
\end{tabular}


Въз основа на функционалните и дистрибутивни характеристики лексемата, която даденият израз представлява, трябва, макар и неизменяема морфологично да бъде причислена към онази изменяема част на речта, чиито типове синтактични връзки реализира, и да се приеме, че нейната парадигма е дефектна поради липсата на някои (или дори всички) морфологични стойности, т. е. да се приеме, че парадигмата ѝ се състои само от една словоформа, или пък да се смята за словоформа от парадигмата на лексема, принадлежаща към определен изменяем клас лексеми (виж по-долу 3.2.3.). Става въпрос за следните неизменяеми групи лексеми:

2.2.3.1. Т.нар. неизменяеми (несклоняеми) съществителни имена. Макар че не се изменят, те запазват своите селективни (синтактични) категории род и число.

Тук трябва да се отбележи, че в българския език (за разлика напр. от полския и руския) почти няма „неизменяеми” съществителни, чиято парадигма се състои само от една словоформа. С много малки изключения всички те се членуват в ед. ч., а някои от тях образуват членувани форми за мн.ч. Срв. напр.:

Всички жени бяха облечени в сари/в сарита. - Cарито иे беше обшито със сърма.

И тримата не познаваха Америка на янките. - Един истински янки никога не постъпва така.

2.2.3.2. Т.нар. неизменяеми (несклоняеми) прилагателни имена не се изменят по род и число, но свободно се съчетават със съществителни имена във всички форми и изпълняват атрибутивна функция (сигнализирана в български винаги от препозицията им спрямо съществителното име), срв. напр.: Тя беше облечена с рокля с каре деколте.

Горните две групи неизменяеми думи трябва да се интерпретират като лексеми - съществителни или прилагателни имена с изцяло или частично дефектна парадигма. В някои случаи синтактичният анализ може да установи омонимия на две графично идентични неизменяеми лексеми. Срв. напр.:

Твоите ицгари са много яващ. - прилагателно име

(36а) Дядо ми обичаше да си пуши ицгарите яваш. - наречие.

(37) В тази част на пиесата има дегато. - съш. име.

(37а) Тази част на пиесата се свири дегато. - наречие. 


\section{3. Универсална формална класификация на лексемите в българския език}

3.0. Наборът от признаци, с които ще бъде конкретизирана дихотомичната класификация при преобразуването ѝ в универсална, зависи на първо място от набора от стойности, които ще бъдат приписани на отделните граматични категории, на следващо място - от допълнителните операции, свързани с формообразуването.

3.1. Стойностите на дадена флективна граматичната категория се определят от подмножествата в множеството словоформи на дадена лексема, абстрахирани въз основа на един от елементите (и неговите изразители), съставящи дадената категория (напр. ед. и мн. ч. в рамките на числото) (срв. Laskowski, 1998; Saloni \& Świdziński, 1985) ${ }^{25}$. Тези стойности се определят най-често с термина граматически значения.

3.1.1. Граматическото значение на флективната категория, а също и неговият изразител се определят още с термина грамема.

3.1.2. Установяването на броя и характера на граматическите значения на дадена категория за даден език изисква правилното разграничаване на понятията лексикално и граматическо значение. Разликата между едното и другото може да бъде най-общо операционално представена в следната таблица:

\begin{tabular}{|c|c|c|}
\hline & \multicolumn{2}{|c|}{ Свойства на значенията: } \\
\hline & лексикални & граматически \\
\hline 1. & $\begin{array}{l}\text { Универсални са за езиците и в инвентара } \\
\text { от езикови значения в даден език са } \\
\text { решително преобладаващата част. }\end{array}$ & $\begin{array}{l}\text { Не са универсални за езиците и в } \\
\text { инвентара от езикови значения в даден } \\
\text { език са винаги решително по-малката част. }\end{array}$ \\
\hline 2. & Образуват отворено множество. & Образуват затворено множество. \\
\hline 3. & $\begin{array}{l}\text { Свързани са с извънезиковата } \\
\text { действителност по-скоро непосредствено. }\end{array}$ & $\begin{array}{l}\text { Свързани са с извънезиковата дейст- } \\
\text { вителност по-скоро опосредствано } \\
\text { (а понякога изобщо не са свързани). }\end{array}$ \\
\hline 4. & $\begin{array}{l}\text { Не са много ясно структурирани (или } \\
\text { изобщо не са структурирани). }\end{array}$ & Структурирани са много ясно*. \\
\hline
\end{tabular}

* В добре организирана система от ясни обобщени опозиции.

(срв. Мелчук, 2013, с. 290)

25 Стойностите на класификационната граматична категория се определят от множеството словоформи на дадена лексема, абстрахирани въз основа на един от елементите (и неговите изразители), съставящи дадената категория (срв. напр. рода на съществителното име) (срв. Saloni \& Świdziński, 1985). 
3.1.3. Особено и важно за формално-морфологичното описание място заемат флективните или словоизменителните значения. Докато лексикалните значения се избират свободно от говорещия според неговите комуникативни намерения, то словоизменителните значения „се налагат [букв. 'натрапват'] на говорещия от неговия език - езикът му предписва да направи един или друг избор, като изхожда от избраните по-рано лексикални значения и съответните знаци" (Мелчук, 2013, с. 291) ${ }^{26}$ (виж по-горе 2.1.6.3.)

3.2. Съвкупността от всички граматически значения, представени от една лексема или допълнително приписани на нея, с указание за всяко от тях коя словоформа (или словоформи) на дадената лексема изразява даденото граматическо значение, се нарича парадигма на дадената лексема (срв. Laskowski, 1998, с. 145; Зализняк, 1967, с. 30). Образно парадигмата може да бъде представена като таблица - набор от клетки, всяка от които е предназначена за словоформа (словоформи) с едно граматическо значение.

3.2.1. Обикновено една клетка е запълнена от една словоформа, т.е. на едно граматическо значение съответства една словоформа. Ако няколко словоформи заемат една клетка, т.е. съответстват на едно граматическо значение, те са варианти. Вариантите могат да бъдат фонологично обусловени (срв. напр. при предлозите $в-в ъ в ; c-c z c)$, стилистично обусловени (срв. напр. днес - днеска) или просто синонимични (срв. напр. мен-мене, теб - тебе, знам - зная и под.).

Постулирането на стилистични варианти зависи от приетата дефиниция за лексема и за омонимия и по-точно от това дали разликата в прагматичната (ситилистичната) характеристика на лексемата ще се приеме като повод за отделяне на омонимна лексема (срв. 2.1.1.).

26 В зависимост от начина, по който „се налагат” граматичните значения, флективните категории могат да бъдат поделени на синтактично зависими и синтактично независими. При първите изборът на словоформа на дадена лексема формално зависи от съставяща в изреченския израз, с която дадената лексема е синтактично свързана (такова е напр. числото на глагола); при вторите граматичното значение не зависи формално от някоя от съставящите, то е семантично обусловено (такдва е напр. времето на глагола); една и съща категория в различни конструкции може да бъде зависима или независима (такова е напр. числото на съществителното име) - срв. Laskowski, 1998, с. 132. Заслужава да се отбележи, че синтактично независимите категории обикновено имат номинативна функция. 
3.2.2. За всеки граматичен клас лексеми може да се състави максимален набор (от клетки), който включва (клетки за) всички възможни граматически значения на всички флективни категории, присъщи на лексемите от този клас. Набор от този тип се определя като функционална парадигма на дадения клас (срв. Laskowski, 1998, с. 146).

3.2.3. Ако в таблицата на дадена лексема има празна клетка (празни клетки), т.е. някакво граматическо значение (граматически значения) не е представено от словоформа, парадигмата на тази лексема е дефектна или непълна. Парадигмата на дадена лексема може да бъде непълна

a) когато наборът от флективни категории на дадена лексема е редуциран (по-малък) в сравнение с набора от възможни за дадения клас флективни категории (в сравнение с функционалната парадигма (срв. напр. singularia tantum от типа младеж, учителство, чиято парадигма е редуцирана по категорията число);

б) когато наборът от граматически значения на поне една от флективните категории на дадена лексема е непълен (срв. напр. лексемата се, която няма форма за подлог и за мн. число) (срв. Laskowski, 1998, с. 147).

3.2.4. Липсата на всички или някои граматични значения в парадигмата на дадена лексема не трябва да се смесва с явлението синкретизъм (Laskowski, 1998, с. 147), при което е налице пълна парадигма с (граматична) омонимия на изразителите на дадено граматическо значение (срв. напр. ед. и мн. ч. на прилагателните от типа български).

3.3. Построяването на универсална класификация, позволяваща формалните морфологични правила да бъдат изчерпателно описани и да бъдат извлечени всички флективни (словоизменителни) типове, изисква да бъде съставен набор от „диагностични” словоформи за всеки от класовете лексеми. Този набор е различен от парадигматичния - той включва само онези словоформи, въз основа на които типовете се различават помежду си, т.е. могат да бъдат извлечени като непресичащи се подмножества на множеството лексеми от даден клас по принципа „колкото различни стойности на елементите от набора, толкова различни флективни типове”.

3.3.1. Анализът на словоформите, целящ да установи диагностичния набор, изисква от своя страна приемането на типове морфологични 
структури на словоформите за отделните класове лексеми. За релевантни за изменяемите класове лексеми се приемат следните морфемни редици:

- словоформи на съществителното и прилагателното име: словообразувателна основа ${ }^{27}+$ окончание (+ членна морфема),

- словоформи на глагола:

словообразувателна основа + тематичен суфикс + формант + окончание.

3.3.2. Съществени за формално-морфологичното описание са граматичните афиксални морфеми в състава на словоформата: тематичен суфикс, формант, окончание и членна морфема. Както се вижда, по своите дистрибутивни свойства тези морфеми са суфикси (афикси, заемащи постпозиция спрямо корена или словообразувателен афикс), а членната морфема в българския език е постфикс (афикс, постпозитивен спрямо окончанието).

3.3.2.1. Приема се постоянна структурата на словоформите на даден клас лексеми, което означава, че всяка от граматичните морфеми е задължително представена в тях, като може да приема нулева стойност (да бъде нулева морфема $)^{28}$.

3.3.2.2. Окончанието е флективна суфиксална морфема, която е изразител на едно или няколко граматически значения на дадена морфологична категория. То заема крайна позиция в редицата от морфеми, съставящи словоформата. Като последна част на словоформата окончанието определя и нейната дистрибутивна характеристика (виж по-горе 1.4.).

При имената в българския език след окончанието може да следва единствено флективната постфиксална членна морфема.

3.3.2.3. Тематичният суфикс е релевантен за формалната структура на българските глаголни словоформи. Различават се два тематични суфикса, които образуват т. нар. сегашна и минала основа: praesentis и aoristi.

3.3.2.4. Формантът (на основата) в най-общ смисъл е онази формообразувателна част, която характеризира структурата на дадена група словоформи и само нея (срв. напр. формант praeteriti в словоформите на имперфект, формант imperativi в словоформите на повелително наклонение).

27 Приемаме, че словообразувателната основа на всички лексеми има следната структура: (префикс / редица префикси +) корен (+ словообразувателен суфикс).

28 За разлика от словообразувателните морфеми, които не могат да приемат нулева стойност - срв. Laskowski, 1998, с. 75. 
3.4. По нататъшното изграждане на универсалната морфологична класификация и абстрахирането на флективните типове трябва да вземе пред вид наред със морфонологичните явления на границата на съставящите словоформата морфеми и промяната в мястото на ударението също и релевантната за нормативността вариантивност (дублетност) (виж по-горе 3.2.1.).

4. Съществени за описанието на изменяемите лексеми в рамките на предложения модел са решенията на някои частни въпроси, които трябва да се вземат на следващия етап. Става дума напр. за интерпретацията и описанието на следните явления:

1) Формите за обръщение на съществителните и прилагателните имена.

2) Мъжколичен и мъжконеличен род: селективна категория на съществителното име и флективна категория на числителните имена и на местоименните прилагателни.

3) Местоименните съществителни (лични местоимения).

4) Причастията - част от парадигмата на глагола или глаголни прилагателни и глаголни наречия.

\section{БИБЛИОГРАФИЯ}

Ajdukiewicz, K. (1985). O spójności syntaktycznej. In K. Ajdukiewicz, Jęzk i poznanie (Pt. 1, pp. 222-242). Warszawa: PWN.

Bogusławski, A. (1978), Towards an operational grammar. Studia Semiotyczne, 8, 29-90.

Grochowski, M. (1982). Zarys leksykologii i leksykografii: Zagadnienia synchroniczne. Toruń: UMK.

Grochowski, M. (1986). Polskie partykuły: Składnia, semantyka, leksykografia. Wrocław: Ossolineum. (Prace Instytutu Języka Polskiego PAN, 62).

Hockett, C. (1968). Kurs językoznawstwa wspótczesnego (Z. Topolińska \& M. Jurkowski, Trans.). Warszawa: PWN.

Laskowski, R. (1998). Fleksja: Podstawowe pojęcia fleksji. In R. Grzegorczykowa, R. Laskowski, \& H. Wróbel (Eds.), Gramatyka wspótczesnego języka polskiego (pp. 125-136). Morfologia. Warszawa: PWN.

Porzeziński, W. (1923). O tzw. częściach mowy słów kilka. Przegląd Humanistyczny, 2, 129-50. Saloni, Z. (1974a). Klasyfikacja gramatyczna leksemów polskich. Język Polski, 54(1), 3-13. Saloni, Z. (1974b). Klasyfikacja gramatyczna leksemów polskich, Język Polski, 54(2), 93-101. Saloni, Z., \& Świdziński, M. (1985). Składnia współczesnego języka polskiego. Warszawa: PWN.

Блумфийлд, Л. (1968). Язык. Москва: Прогресс.

Зализняк, А. (1967). Русское именное словоизменение. Москва: Наука. 
Леков, И. (1972). Единство от лексикално и граматично съдържание на славянските части на речта и неговото противоречиво развитие. Jazykovedný časopis, 23(2), 107-113.

Мелчук, И. (2013). Курс по общз морфология (Б. Блажев, Trans.) (Pt. 1). София: УИ „Св. Климент Охридски“.

Пенчев, Й. (1984). Строеж на българското изречение. София: Издателство на БАН.

Проект „Нормативна граматика на съвременния български език“: Анотация (Manuscript). (2017). ИБЕ при БАН, София.

Станчева, Р., Томов, М., Паскалев, Н., Кунева, И., \& Микова, Л. (2017). Формално описание на инвентара от граматични средства в българския език (като етап от разработването на нормативна граматика). In Доклади от Международната юбилейна конферениия на Института за български език „Проф. Любомир Андрейчин“ (София, 15-16 май 2017 година) (Pt. 2, pp. 107-111). София: Институт за български език. Retrieved from http://ibl.bas.bg/Proceedings_IBL_Conference_2017_Volume_II.pdf

Фортунатов, Ф. (1956). Сравнительное языковедение: Общий курс. In Ф. Фортунатов, Избранные труды (Pt. 1). Москва: Наука.

\section{BIBLIOGRAPHY}

\section{(TRANSLITERATION)}

Ajdukiewicz, K. (1985). O spójności syntaktycznej. In K. Ajdukiewicz, Język i poznanie (Pt. 1, pp. 222-242). Warszawa: PWN.

Blumfiǔld, L. (1968). IAzyk. Moskva: Progress.

Bogusławski, A. (1978), Towards an operational grammar. Studia Semiotyczne, 8, 29-90.

Fortunatov, F. (1956). Sravnitel'noe iazykoznanie: Obshchiǔ kurs. In F. Fortunatov, Izbrannye trudy (Pt. 1). Moskva: Nauka.

Grochowski, M. (1982). Zarys leksykologii i leksykografii: Zagadnienia synchroniczne. Toruń: UMK.

Grochowski, M. (1986). Polskie partykuły: Składnia, semantyka, leksykografia. Wrocław: Ossolineum. (Prace Instytutu Języka Polskiego PAN, 62).

Hockett, C. (1968). Kurs językoznawstwa współczesnego (Z. Topolińska \& M. Jurkowski, Trans.). Warszawa: PWN.

Laskowski, R. (1998). Fleksja: Podstawowe pojęcia fleksji. In R. Grzegorczykowa, R. Laskowski, \& H. Wróbel (Eds.), Gramatyka współczesnego języka polskiego (pp. 125-136). Morfologia. Warszawa: PWN.

Lekov, I. (1972). Edinstvo ot leksikalno i gramatichno sŭdŭrzhanie na slavianskite chasti na rechta i negovoto protivorechivo razvitie. Jazykovedný časopis, 23(2), 107-113.

Melchuk, I. (2013). Kurs po obshta morfologiia (B. Blazhev, Trans.) (Pt. 1). Sofiia: UI “Sv. Kliment Okhridski”.

Penchev, Ĭ. (1984). Stroezh na bŭlgarskoto izrechenie. Sofiia: Izdatelstvo na BAN. 
Porzeziński, W. (1923). O tzw. częściach mowy słów kilka. Przegląd Humanistyczny, 2, 129-50. Proekt "Normativna gramatika na sŭvremenniia bŭlgarski ezik": Anotatsiia (Manuscript). (2017). IBE pri BAN, Sofiia.

Saloni, Z. (1974a). Klasyfikacja gramatyczna leksemów polskich. Język Polski, 54(1), 3-13.

Saloni, Z. (1974b). Klasyfikacja gramatyczna leksemów polskich, Język Polski, 54(2), 93-101. Saloni, Z., \& Świdziński, M. (1985). Składnia współczesnego języka polskiego. Warszawa: PWN. Stancheva, R., Tomov, M., Paskalev, N., Kuneva, I., \& Mikova, L. (2017). Formalno opisanie na inventara ot gramatichni sredstva v bŭlgarskiia ezik (kato etap ot razrabotvaneto na normativna gramatika). In Dokladi ot Mezhdunarodnata iubileina konferentsiia na Instituta za bŭlgarski ezik "Prof. Liubomir Andreŭchin" (Sofiia, 15-16 mă̌ 2017 godina) (Pt. 2, pp. 107-111). Sofiia: Institut za bŭlgarski ezik. Retrieved from http://ibl.bas.bg /Proceedings_IBL_Conference_2017_Volume_II.pdf

Zalizniak, A. (1967). Russkoe imennoe slovoizmenenie. Moskva: Nauka.

\section{Zasady formalnego opisu bułgarskich leksemów odmiennych jako komponentu gramatyki normatywnej}

Formalny opis inwentarza środków gramatycznych języka bułgarskiego jako komponent jego gramatyki normatywnej powinien stanowić podstawę do adekwatnego wyodrębnienia i zdiagnozowania problemów normatywnych. Oznacza to, że fakty językowe powinny być opisane ściśle i wyczerpująco bez jakiejkolwiek z góry założonej interpretacji normatywnej. Osiągnięcie tego celu wydaje się możliwe, jeśli do opisu podejść jak do zadania zbudowania uniwersalnej klasyfikacji form języka bułgarskiego rozumianej jako klasyfikacji, w której każda z cech klasyfikacyjnych realizuje się poprzez którąś ze swoich wartości w każdym klasyfikowanym obiekcie.

Praca ta stanowi próbę ustalenia zasad budowania klasyfikacji jednostek leksykalnych języka bułgarskiego relewantnej dla ich formalnego opisu morfologicznego jako przejścia od klasyfikacji dychotomicznej do uniwersalnej.

Słowa kluczowe: gramatyka normatywna, bułgarskie leksemy odmienne, formalny opis

\section{Rules of a Formal Description of Bulgarian Inflected Lexemes as a Component of Normative Grammar}

A formal description of the set of grammatical means in Bulgarian as a component of its normative grammar should form the basis for adequate distinction and diagnosis of normative problems. It means that linguistic facts should be described precisely and exhaustively and without any presupposed normative interpretation. Accomplishment of such an objective may be 
feasible if the description is treated as the task of building the universal classification of forms in the Bulgarian language understood as the classification in which each of the classifying features finds its fulfilment through one of its values in each of the objects classified.

The study is an attempt to determine the rules of building the classification of Bulgarian lexical items relevant to their formal morphological description as a transition from dichotomous to universal classification.

Keywords: formal description, Bulgarian inflected lexemes, normative grammar

\section{Notka o autorce}

Viara Maldijeva (Вяра Малджиева) (maldzieva@gmail.com) - prof. dr hab. Viara Maldjieva pracuje w Katedrze Bałkanistyki UMK w Toruniu. Obszary jej slawistycznych badań konfrontatywnych to: składnia i semantyka; słowotwórstwo, frazeologia i leksykografia. Jest autorem monografii m. in. Non-inflected Parts of Speech in the Slavonic Languages (Syntactic Characteristics) (1995), Modalność: hipotetyczność, irrealność, optatywność i imperatywność, warunkowość. Gramatyka konfrontatywna bułgarsko-polska, t. VI, cz. 3 (2003), Słowotwórstwo, Gramatyka konfrontatywna bułgarsko-polska, t. IX (2009).

Viara Maldjieva (maldzieva@gmail.com) - Prof. Viara Maldjieva works at the Department of Balkan Studies at the Nicolaus Copernicus University in Torun. The areas of her Slavic comparative research are: syntax and semantics, word formation, phraseology and lexicography. She is the author of monographs, among others Non-inflected Parts of Speech in the Slavonic Languages (Syntactic Characteristics) (1995), Modalność: hipotetyczność, irrealność, optatywność i imperatywność, warunkowość. Gramatyka konfrontatywna bułgarsko-polska, t. VI, cz. 3 [Modality: hypotheticality, irreality, optativity and imperative, conditionality. Bulgarian-Polish confrontative grammar, vol. VI, part. 3] (2003), Słowotwórstwo, Gramatyka konfrontatywna bułgarsko-polska, t. IX [Word formation, Bulgarian-Polish confrontative grammar, vol. IX] (2009). 